\title{
Verdelgen of verheffen?
}

\section{De evolutietheorie en de maakbaarheid van de mens}

\author{
RaF De Bont
}

Als menselijke eigenschappen vandaag in een evolutionair daglicht worden geplaatst, is dat zelden om hun maakbaarheid te benadrukken. Met name in de evolutionaire psychologie - een wetenschapstak die sinds de jaren 1990 een groeiend succes kent - wordt graag de aandacht gericht op de biologische verankering van het menselijk gedrag. Dit heeft evolutionair-psychologen de beschuldiging van 'genetisch determinisme' opgeleverd, een etiket dat ze zelf altijd hebben afgewezen. De verdedigers van de discipline geven echter wél toe dat de evolutionaire psychologie duidelijk 'een minder kneedbare mens' toont, dan de 'traditionele menswetenschappen.' Met hun nadruk op evolutionair gegroeide predisposities geven ze in ieder geval een meer deterministisch beeld van het menselijk gedrag dan tot dusver gebruikelijk was. Ze benadrukken het gewicht van het verleden en maken mensen op die manier tot 'levende fossielen.'

Vaak wordt in de evolutionaire psychologie benadrukt dat natuurlijke selectie de basis van het menselijke brein heeft vastgelegd in het pleistoceen, in de periode tussen 1,8 miljoen en 10.000 jaar geleden. De kenmerken die toen voortplanting en overleving begunstigden, zouden dan ook tot vandaag in ons genetisch materiaal ingeschreven zijn en bijgevolg ons gedrag sturen. Volgens de evolutionair-pyschologen eten we graag vet en suiker omdat calorierijke producten schaars waren in het prehistorische verleden. Mannen hebben een goed oriëntatievermogen omdat hen dat hielp tijdens de pleistocene jacht, terwijl dit minder cruciaal was bij het verzamelen van bessen - de vrouwelijke taak. Mannen vallen voor vrouwen met een heup-tailleverhouding van 0,7 omdat dit, opnieuw in het pleistoceen, de beste garanties tot voortplanting bood. ${ }^{3}$ Tenslotte gaan mannen omwille van hun prehistorische genen ook vaker vreemd dan vrouwen. Volgens de Nederlandse bioloog en schrijver van populariserende boeken, Midas Dekkers is dit laatste gedrag zonder meer eigen aan de mannelijke natuur. In het (feministische) maandblad Oprij liet hij optekenen: 'Bij negenennegentig procent van de zoogdieren makkt het mannetje een wip en is dan weg. Ook bij de apen is dat zo, en wij zijn apen. ${ }^{4}$

1 G. Vandermassen, 'R-evolutionaire psychologie', Wonder en is gheen wonder. Tïdschrift voor wetenschap en rede, nov. 2000. http://www.skepp.be/artikels/evolutie/r-evolutionaire-psychologie.

2 De typering komt uit: D.M. Buss, 'Evolutionary psychology. A new paradigm for psychological science', Psychological Inquiry, VI (1995) 10.

3 De aangehaalde voorbeelden zijn maar enkele van de evolutionair-psychologische topoi die in de populariserende literatuur over het onderwerp steeds terugkeren. Internationaal erg invloedrijk was: J.H. Barkow, L. Cosmides, J. Toby, ed., The adapted mind. Evolutionary psychology and the generation of culture (Oxford, 1992). Een goed overzicht van evolutionair-psychologische standpunten wordt ook gegeven in: Buss, 'Evolutionary psychology', 1-30. 
Tegenstanders beweren dat dergelijke theorieën teruggaan op het intellectueel imperialisme van een bepaald type (al te simplistische) biologie. ${ }^{5}$ Als alternatief verdedigen de critici van de evolutionaire psychologie veelal de autonomie van het culturele veld. In het bijzonder ter linkerzijde - waar het geloof in de maakbare mens traditioneel het sterkst is - hebben verschillende commentatoren het menselijk gedrag op die manier willen vrijwaren van biologisch determinisme. Dit verklaart meteen waarom hun enthousiasme voor evolutionaire psychologie, evolutionaire sociologie of evolutionaire ethiek erg beperkt is gebleven. ${ }^{6}$

In dit alles verschilt de huidige situatie duidelijk van deze in de late negentiende en vroege twintigste eeuw. Naast wetenschappers die deterministische consequenties aan de evolutietheorie verbonden, bestond er in deze periode immers óók een belangrijke groep die haar evolutionaire opvattingen precies gebruikte om de menselijke maakbaarheid te benadrukken. Deze laatste strekking, die ik als 'evolutionair voluntarisme' zou willen typeren, lijkt op bepaalde momenten zelfs die van de deterministen te hebben overklast. In dit opstel wordt onderzocht hoe de twee stromingen zich ten opzichte van elkaar verhielden in het laat-negentiende en vroeg-twintigste-eeuwse België. Daarbij wordt nagegaan op welke biologische ideeën ze zich beriepen en welke maatschappelijke consequenties ze daaraan verbonden.

\section{Evolutionisten en bun milieu}

De evolutionaire denkbeelden van zowel de voluntaristen als de deterministen werden ontwikkeld in een welbepaald sociologisch milieu. Niet iedereen in het laatnegentiende- en vroeg-twintigste-eeuwse België was immers geneigd om de menselijke gedragingen en capaciteiten in het licht van de evolutietheorie te bekijken. Om te beginnen waren het voor het overgrote deel (zij het niet uitsluitend) vrijzinnigen die zich aan een dergelijke onderneming zouden wagen. Katholieken kantten zich niet per definitie tegen de evolutietheorie, maar, vanuit hun geloof dat het natuurlijke lichaam moest worden onderscheiden van een geest met bovennatuurlijke oorsprong, hadden ze meestal wél moeite met de uitbreiding van de biologie naar het sociale veld. In liberale en socialistische hoek bestond die schroom veel minder.

De intellectuelen die maatschappelijke conclusies aan het evolutionisme zouden verbinden, moeten vooral (zij het opnieuw niet uitsluitend) worden gezocht in de

4 Geciteerd in T. de Hoog, 'Eeuwige kunnestrijd', Groene Amsterdammer, 15 dec. 1999. Het citaat komt uit Opzij. Feministisch maandblad.

5 Kritiek op de evolutionaire psychologie kwam uit filosofische hoek, maar ook verschillende biologen (als Stephen Jay Gould, Richard Lewontin en Steven Rose) distantieerden zich van de discipline. Zie onder meer het opgemerkte: H. Rose, S.P.R. Rose, ed., Alas, poor Darwin. Arguments against evolutionary psychology (Londen, 2001).

6 Hiermee plaatste links zich in een naoorlogse traditie, waarin cultuur als grotendeels onafhankelijk van de biologie werd opgevat. De invloedrijke UNESCO-verklaringen van de jaren 1950 over menselijke 'rassen' kunnen hier als voorbeeld gelden. Zie: J. Gayon, 'Faut-il proscrire en biologie l'expression 'races humaines'? UNESCO 1950-1951', L'avonture bumaine, XII (2002) 9-40. De twee geschetste 'kampen' zijn uiteraard niet erg scherp af te lijnen. Niet iedereen die vandaag politiek links te situeren valt, gelooft immers in een volledig maakbare mens en samenleving. Tezelfdertijd hebben verschillende professionele evolutionair-psychologen erkend dat de menselijke cultuur toch minstens gedeeltelijk aan de invloed van genetische predisposities ontsnapt. 
intellectuele milieus rond de Brusselse universiteit. ${ }^{7}$ Het was ook deze universiteit geweest die zich, vanaf de late jaren 1880, had kunnen opwerpen als het Belgische centrum van de evolutionaire biologie. ${ }^{8}$ Toch waren het niet de biologen die zich het meest zouden onderscheiden met evolutionistische bedenkingen over het menselijke gedrag en de inrichting van de samenleving. Ze gaven wel enkele aanzetten in het debat, maar het waren vooral vertegenwoordigers van relatief 'jonge' wetenschapstakken als de antropologie, de sociologie, de criminologie, de pedagogie en de eugenetica, die deze verder zouden uitwerken.

$\mathrm{Al}$ deze wetenschappen werden in de besproken periode gekenmerkt door een relatief beperkte mate van institutionalisering. Ze ontwikkelden zich dan ook niet zozeer binnen de Brusselse universiteit zelf, maar wél in nieuwe sociëteiten en instituten die daar ideologisch en institutioneel in min of meerdere mate mee waren verbonden. Het ging daarbij om organisaties als de Société d'anthropologie de Bruxelles, het Institut de sociologie Solvay en de Société belge d'eugénique (opgericht in respectievelijk 1882, 1902 en 1919). ' De propagandisten van nieuwe wetenschapstakken die elkaar in een dergelijk kader ontmoetten, richtten zich zowel methodologisch als inhoudelijk sterk op de prestigieuze, geprofessionaliseerde natuurwetenschappen. In het bijzonder de evolutionaire biologie gold daarbij als een cruciaal referentiepunt.

Hoewel de genoemde sociëteiten en instituten in naam steeds op één enkele wetenschap waren gericht, was de interesse van hun leden zonder meer interdisciplinair. Dit hing ongetwijfeld ook samen met het synthesestreven dat, ondanks een toenemende specialisatie, opgang maakte in de Belgische wetenschapswereld van de late negentiende eeuw. ${ }^{10}$ Het kan tegelijkertijd de belangrijke overlappingen verklaren die bestonden in de ledenbestanden van de angehaalde organisaties. Juristen en ingenieurs waren daarin over het algemeen goed vertegenwoordigd, maar de kerngroep bestond meestal uit artsen - wat meteen ook de sterk medische oriëntatie van de aangehaalde jonge wetenschapstakken verklaart. Evolutionair-biologen speelden er zelden een echt prominente rol, maar dit neemt niet weg dat hun ideeën via

7 Over die Brusselse milieus, zie onder meer: P.F. Daled, Spiritualisme et matérialisme an XIXe siècle. L'Université Libre de Bruxelles et la religion (Brussel, 1998) en K. Wils, De omweg van de wetenschap. Het positivisme en de Belgische en Nederlandse intellectuele cultuur, 1845-1914 (Amsterdam, 2005) 271-283 en 304326.

8 De opkomst van die 'Brusselse groep' wordt uitgebreid behandeld in: R. De Bont, Darwins kleinkinderen. De evolutietheorie in België, 1865-1945 (Nijmegen, 2008).

9 Over deze organisaties, zie: L. Beyers, 'Rasdenken tussen geneeskunde en natuurwetenschap. Emile Houzé en de Société d'Anthropologie de Bruxelles, 1882-1921', in: J. Tollebeek, G. Vanpaemel, K. Wils, ed., Degeneratie in België (Leuven, 2003) 43-77; F. van Langenhove, 'L'Institut de sociologie Solvay au temps de Waxweiler', Revue de l'Institut de Sociologie, III (1978) 229-261; W. de Raes, 'Eugenetika in de Belgische medische wereld tijdens het interbellum', Belgisch tijdschrift voor Nieunste Geschiedenis, XX (1989) 399-464.

10 De meest duidelijk exponent van (en de drijvende kracht achter) dit synthesestreven was ongetwijfeld de Brusselse chemist, mecenas en filantroop Ernest Solvay. Zie: I. Stengers, 'La pensée d'Ernest Solvay et la science de son temps', in: A. Despy-Meyer, D. Devriese, Ernest Solvay et son temps (Brussel, 1997) 149164. 
persoonlijke contacten wel degelijk doorsijpelden in de wereld van de antropologen, sociologen, pedagogen en tutti quanti.

\section{Biologische axioma's}

Hoewel ze de thematiek zelden echt uitwerkten, leverden de Belgische evolutionairbiologen toch enkele axioma's die een leidraad konden zijn bij de inrichting van de samenleving. Een eerste van dergelijke biologische grondstellingen was dat de natuur onmogelijk 'egalitair' kon zijn. Edouard van Beneden, de invloedrijke Luikse celbioloog en evolutionist, was daar in een opmerkelijke lezing voor de Académie royale de Belgique in 1883 erg duidelijk over. 'De natuur', zo stelde hij toen, 'kent geen sociale gelijkheid; ze betaalt naargelang de geleverde diensten, de nuttelozen worden door haar afgewezen.' De consequenties van een dergelijke uitspraak beperkten zich volgens Van Beneden overigens niet tot de wereld van de biologie. Ze heetten ook ten zeerste van belang te zijn voor de bredere 'filosofische concepties en voor de sociale beweging in het algemeen. ${ }^{11}$ De embryoloog Marc de Selys-Longchamps, een Brussels leerling van Van Beneden, verwoordde het veertig jaar later in dezelfde Academie nog wat scherper. De differentiatie van de levende wezens, zo stelde hij, moest als één van de mooiste kwaliteiten van de levende materie worden gezien. Egalitarisme - 'de plaag van alle demagogieën' - leidde dan ook zonder meer tot een nivellering naar beneden. ${ }^{12}$

Zowel Van Beneden als De Selys-Longchamps hielden zich voornamelijk op in een liberaal milieu. ${ }^{13}$ Hun denkbeelden over ongelijkheid in de natuur én in de samenleving werden echter ook door collega's met een socialistische overtuiging gedeeld. In L'Avenir Social, een tijdschrift van de arbeidersbeweging, benadrukte de dierpsycholoog en evolutionist Louis Verlaine in 1928 dat ongelijkheid van kenmerken de basis uitmaakte van elke biologische en sociale organisatie. Door economische onrechtvaardigheden weg te werken, kon volgens Verlaine wel een gelijkheid aan kansen worden gecreëerd, maar een gelijkheid in resultaten gold als een utopie. Daarenboven was hij van mening dat het socialisme niet nobeler moest zijn dan de natuur zelf. ${ }^{14}$

De natuur kon dan wel onmogelijk egalitaristisch zijn, voorrechten voor bepaalde groepen waren eveneens uit den boze. In de reeds aangehaalde lezing voor de Academie was Van Beneden ook hierover erg expliciet: 'De natuur] accepteert het principe van de onderwerping, maar ze weigert elk privilege. ${ }^{15}$ De zoöloog en vooraanstaande vrijmetselaar Paul Pelseneer was het met hem eens. Ongelijkheden moest men accepteren, zo stelde Pelseneer, maar ze mochten onder geen beding 'degenereren' in vastgeroeste klassen. Vanuit een evolutionair denkkader heette het daarenboven dat zowel egalitarisme als maatschappelijke privileges een rem op de

11 E. van Beneden, 'La biologie et l'histoire naturelle', Bulletins de l'Académie royale des sciences, des lettres et des beaux-arts de Belgique [BAR], reeks 3, VI (1883) 903-904, 909.

12 M. de Selys-Longchamps, 'L'égalitarisme et la biologie', BAR, reeks 5, XV (1929) 1130.

13 Van Beneden onderhield goede contacten met de liberale staatsman Walthère Frère-Orban (die de nodige fondsen voor het Luikse Institut de zoölogie zou vrijmaken). De Selys-Longchamps op zijn beurt kwam zeer duidelijk uit een liberale familie (zowel zijn vader als zijn grootvader waren senator voor de Liberale Partij).

14 L. Verlaine, 'Le socialisme et les lois biologiques', L'Avenir Social, IV (1928) 152-162.

15 Van Beneden, 'La biologie et l'histoire naturelle', 909. 
evolutie betekenden. ${ }^{16}$ De biologie leverde op die manier dus een pleidooi voor het belang van sociale mobiliteit. Een soortgelijke overweging bracht De Selys-Longchamps in zijn lezing voor de eerbiedwaardige Academie zelfs tot de wat geëxalteerde uitroep 'Honneurs aux parvenus!' ${ }^{17}$

Een derde aangrijpingspunt voor maatschappelijke aanbevelingen vonden de Belgische biologen in het principe van de 'fysiologische verdeling van de arbeid.' Met dat concept, gepopulariseerd door de Franse naturalist Henri Milne-Edwards, werd verwezen naar de functionele specialisatie van verschillende lichaamsdelen. De lever, het hart en de longen hadden zich allemaal in een bepaalde functie gespecialiseerd en hielden op die manier elkaar in leven, aldus Milne-Edwards. Hoewel Milne-Edwards de interne relaties van het organisme centraal plaatste, zouden verschillende biologen diens concept ook gebruiken om de externe relaties tussen verschillende organismen uit te drukken. In verschillende dierlijke samenlevingen, zo werd vastgesteld, was het werk verdeeld en was er specialisatie opgetreden. In het bijzonder de complexe samenlevingen van sociale insecten golden daarbij als voorbeeld. Vaak werd de fysiologische beeldspraak daarenboven nog eens uitgebreid met een evolutionistische interpretatie. Het heette dan dat de evolutionaire perfectionering in een steeds verdere verdeling van arbeid zou resulteren. Vanuit dat standpunt was de stap naar maatschappelijk advies uiteraard klein. ${ }^{18}$ Zo was de Brusselse zoöloog Auguste Lameere er in 1915 van overtuigd dat 'de superioriteit van de menselijke samenleving een functie is van de verdeling van arbeid. ${ }^{19}$

De biologische lofzang op de arbeidsverdeling bevestigde tenslotte opnieuw het belang van differentiatie en dus het nefaste karakter van 'egalitarisme'. 'Teder volgens zijn taak' was volgens De Selys-Longchamps dan ook het devies voor de enige 'échte gelijkheid', 'de enige die echt realiseerbaar is. ${ }^{20}$ Vanuit een dergelijke analyse komt men uiteraard al snel tot een hiërarchisch maatschappijbeeld, waarin de rol van een bepaalde elite cruciaal wordt geacht. Met name de intellectuele elite - of in de organicistische metafoor: het brein van het organisme - werd door verschillende biologen een leidinggevende taak toegemeten in de evolutionaire vooruitgang. Dat de biologen zichzelf tot die elite rekenden, spreekt voor zich. ${ }^{21}$

16 P. Pelseneer, 'La solidarité entre les individus et entre les nations', Bulletin des Travaux du Suprême Conseil de Belgique, XLVII (1903-1904) 42.

17 De Selys-Longchamps, 'L'égalitarisme et la biologie', 1140.

18 Over de impact van Milne-Edwards' concept: C. Limoges, 'Milne-Edwards, Darwin, Durkheim and the division of labour. A case study in reciprocal conceptual exchanges between the social and the natural sciences', I.B. Cohen, ed., The natural sciences and the social sciences: some critical and historical perspectives (Dordrecht, 1994) 317-343; P. Tort, 'Division du travail physiologique et division du travail social', in: Idem, ed., Dictionnaire du darwinisme et de l'évolution (Parijs, 1996) I, 1221-1237.

19 A. Lameere, Les sociétés animales. Cours fait au Muséum d'bistoire naturelle (Parijs, 1915) 94.

20 De Selys-Longchamps, 'L'égalitarisme et la biologie', 1144.

21 Zie onder meer: Julius MacLeod, Inleiding tot de natuurkunde der maatschappijen (Gent, 1902) 14; Verlaine, 'Le socialisme et les lois biologiques', 158-159; De Selys-Longchamps, 'L'égalitarisme et la biologie', 1137-1140. 


\section{Determinisme: De strijd als 'natuurwet'}

De aangehaalde biologische grondregels werden door verschillende sociale wetenschappers opgepikt en verder uitgewerkt. Het is daarbij opvallend dat zowel deterministen als voluntaristen de noodzaak van ongelijkheid, het nefaste karakter van privileges en het belang van de arbeidsverdeling onderschreven. Ze waren echter wél geneigd deze elementen op verschillende wijzen in te vullen.

In het deterministisch discours werd in de eerste plaats de ongelijkheid benadrukt. Die werd cruciaal geacht omdat ze een voorwaarde bood voor de natuurlijke selectie. Hoewel zeker niet alle wetenschappers in het laat-negentiende en vroeg-twintigsteeeuwse België selectie als het belangrijkste mechanisme achter de evolutie zagen, benadrukten de meeste sociaal-deterministen er expliciet het belang van. Het leverde hen immers een 'blind' systeem, dat de tussenkomst van een menselijke wil leek uit te sluiten en dat louter op een materialistisch niveau kon worden begrepen. Dankzij de 'strijd om het bestaan' en de natuurlijke selectie die daarop volgde, kwamen superieure elementen zonder meer bovendrijven, of het nu ging om individu's of om hele rassen.

De invloedrijkste Belgische auteur die dit mechanisme beschreef op het niveau van het individu was ongetwijfeld de Brusselse gerechtsarts en socioloog Jules Dallemagne. $^{22}$ Die was in 1886 de eerste in België om een handboek sociologie te publiceren een wetenschap die hij presenteerde als een specifiek onderdeel van de biologie. Als zelfverklaard determinist meende Dallemagne immers dat het gedrag van individu's kon worden teruggebracht tot een geheel van fysiologische reflexen. De belangrijkste daarvan heetten verankerd te zijn in het streven naar zelfbehoud en het streven naar het behoud van de soort. Deze streefdoelen golden tegelijkertijd als de ultieme verklaring van elk menselijk gedrag, als de sleutel van de evolutie en als de bron van alle vooruitgang. ${ }^{23}$

Eén van de belangrijkste focuspunten van Dallemagnes eigenzinnige sociologie was het fenomeen van de degeneratie. Met dit concept trachtte hij een hele reeks maatschappelijke en medische problemen te beschrijven én te verklaren - gaande van tuberculose en epilepsie, over pauperisme en anarchisme, tot zelfmoord en criminaliteit. $^{24}$ Daarbij waren volgens Dallemagne twee mechanismen in het spel: de lamarckistische overerving van verworven eigenschappen enerzijds en de darwinistische natuurlijke selectie anderzijds. De degeneratie werd in eerste instantie uitgelokt door een negatieve milieu-invloed, maar vervolgens leverde die ook een nadeel op in de struggle for life. Op die manier werden de inferieure gedegenereerden ook relatief snel weer geëlimineerd. Degeneratie heette dan ook een normaal fenomeen te zijn dat een onderdeel was van een globale op vooruitgang gerichte evolutie. ${ }^{25}$ Het was de manier waarop een maatschappij zich ontdeed van zijn verschoppelingen. De ondergang van

22 Over hem, zie: D. Jaquet, 'Notice sur la vie et les travaux de Jules Dallemagne', Université Libre de Bruxelles. Rapport sur l'année académique 1922-1923 (Brussel, 1924) 27-31.

23 J. Dallemagne Principes de sociologie (Brussel-Parijs, 1886) 1-9 en 34-38.

24 Het hele gamma aan degeneratievormen wordt behandeld in: Idem, Dégénérés et déséquilibrés (Brussel, 1894).

25 Hiermee volgde hij verschillende buitenlandse theoretici die degeneratie aan evolutionaire vooruitgang koppelden. Zie: R.A. Nye, 'Sociology and degeneration. The irony of progress', in: J.E. Chamberlain, S.L. Gilman, ed., Degeneration. The dark side of progress (New York, 1985) 49-71. 
de gedegenereerden was dan ook absoluut geen blamage. Het ging om 'eervolle doden. ${ }^{26}$

Ook het principe van de verdeling van de arbeid kreeg een rol toegemeten in dit proces. Dergelijke verdeling van functies binnen het sociale lichaam betekende voor Dallemagne geenszins dat 'de zwakken' steun moesten verwachten van 'de sterken'. Integendeel, de verdeling van arbeid kon de bestaansomstandigheden precies delicater maken, de aanpassing van individu's aan hun milieu bemoeilijken en op die manier de eliminatie van zwakken versnellen. De arbeidsverdeling tilde de samenleving op een hoger niveau, maar dit maakte het voor de 'uitgeblusten' alleen maar moeilijker om bij te blijven. ${ }^{27}$

Het succes van Dallemagnes opvattingen over de natuurlijke selectie op het niveau van het individu bleef al bij al beperkt. ${ }^{28}$ Een iets ruimere aanhang vond de idee dat de selectie niet zozeer het gevolg was van een concurrentie tussen individu's als wel tussen rassen. De arts Emile Houzé, jarenlang het boegbeeld van de Société d'Anthropologie, zou deze redenering nadrukkelijk verdedigen - althans in het begin van zijn carrière als fysisch antropoloog. ${ }^{29}$ In de jaren 1880 en 1890 schetste hij het beeld van een alomtegenwoordige 'natuurwet' die tegen elk 'egalitair sentimentalisme' inging. Die natuurwet was kort te typeren als 'rassenstrijd', of ook als: 'de eeuwige oorlog waarin de middelmatigen worden verjaagd door de beteren; de waardelozen blijven daarbij achter en worden geëlimineerd. ${ }^{30}$ De verdeling van de arbeid speelde ook hierin een rol, omdat ze geacht werd precies één van de elementen te zijn die de superioriteit van de hogere rassen uitmaakte. ${ }^{31}$

In de twintigste eeuw werden soortgelijke denkbeelden verdedigd door de prehistorisch archeoloog Aimé Rutot - die er nochtans een zaak van maakte om het op zoveel mogelijk punten met Houzé oneens te zijn. ${ }^{32}$ Rutot, eveneens lid van de Société d'anthropologie en conservator in het Natuurhistorisch museum van Brussel, beschreef in verschillende wetenschappelijke artikelen hoe Neanderthalers (en andere menselijke 'voorlopers') door de moderne mens werden verjaagd, tot slaaf gemaakt en opgegeten. ${ }^{33}$ Met tentoonstellingen voor zijn museum vertaalde hij deze visie naar het

26 J. Dallemagne, 'Dégénérescence individuelle et dégénérescence collective', Revue de Belgique, 2e reeks, XIX (1897) 48 en 63-67.

27 Idem, Dégénérés et déséquilibrés, 151.

$28 \mathrm{Al}$ sloten enkele politiek commentatoren bij zijn denkbeelden aan. Zie bijvoorbeeld: A. Brialmont, 'De l'accroisement de la population et de ses effets dans l'avenir', BAR, reeks 3, XXXII (1896) 884-924; J. van Drunen, 'Socialisme scientifique', Revue de Belgique, reeks 2, XXX (1898) 343-349;

29 In later werk benadrukte hij steeds meer het belang van lamarckistische aanpassing aan het milieu en steeds minder de rol van de darwinistische natuurlijke selectie. Vergelijk bijvoorbeeld: E. Houzé, L'Aryen et l'anthropologie. Etude critique (Brussel, 1906).

30 Idem, 'Rapport annuel', Bulletin de la Société d'anthropologie de Bruxelles [BS AB], VII (1888-1889), 169.

31 Houzé gaf wel aan dat die arbeidsverdeling de struggle for life tussen individu's binnen een ras kon afzwakken, maar hij trok deze redenring allerminst door naar de verhouding tussen rassen. Idem, 'Le progrès de l'intelligence sont dus à la sélection naturelle', BS AB, XIII (1894-1895) 38.

32 Over Rutot en zijn wetenschappelijke denkbeelden: R. De Bont, 'The creation of prehistoric man. Aimé Rutot and the eolith controversy, 1900-1920', Isis: An International Review devoted to the History of Science an its Cultural Influences, XCIV (2003) 604-630.

33 A. Rutot, 'Note sur l'âge de la mâchoire de Mauer (Homo Heidelbergensis O. Schoetensack) suivi d'un 
grote publiek. De centrale gedachte achter zijn opvattingen was daarbij steeds dat rassen met een progressieve of 'evolutieve' manier van denken per definitie die groepen verdrongen die gekenmerkt werden door een stagnerende mentaliteit. Tot deze laatste rekende hij overigens niet alleen de Neanderthalers, maar ook de Australische aboriginals, de Bosjesmannen en de Noord-Amerikaanse indianen. ${ }^{34}$

De deterministische visie, die wetenschappers als Dallemagne, Houzé en Rutot koppelden aan de natuurlijke selectie, had uiteraard ook consequenties voor hun visie op het menselijk handelen. Aangezien in hun redenering de 'natuurwet' als vanzelf naar 'vooruitgang' leidde, pleitten ze voor politieke non-interventie. Wetenschap resulteerde met de woorden van Dallemagne in een 'gezond vertrouwen in de natuurprocessen, in die progressieve evolutie die ons uit het niets heeft getrokken en ons in de voorhoede van de levende dingen heeft gebracht. ${ }^{35}$ Vanuit een dergelijke overtuiging meenden deterministische auteurs dat ondersteuning van de zwakken steeds nadelige effecten moest hebben. Het vervalste immers de op vooruitgang gerichte struggle for life. De kritiek van auteurs als Dallemagne op de 'sentimentalistische' filantropie was echter nooit ondubbelzinnig. Als overtuigde determinist moest Dallemagne immers óók de filantropische hulpprogramma's als een onvermijdelijk resultaat van de alomtegenwoordige 'natuurwet' zien. Echte beleidskeuzes zijn in een dergelijk discours niet te vinden. Elke keuze heette immers per definitie een illusie te zijn.

Voluntarisme: Veredelen zonder te verdelgen

De denkbeelden van Dallemagne, Houzé en Rutot waren onderhevig aan kritiek. De Gentse bioloog en socioloog Julius Mac Leod bijvoorbeeld, nochtans een overtuigd evolutionist, distantieerde zich herhaaldelijk van de deterministen.

\footnotetext{
'Zij verkeeren in de meening', aldus Mac Leod in 1902, 'dat de mensch zich aan de wetten der Natuur, en dus ook aan de sociale natuurwetten, noodzakelijk moet onderwerpen, en daardoor worden zij gebracht tot een ontzenuwend fatalisme, dat zelf aan ziekelijke ontmoediging het aanzijn geeft. De studie der natuurlijke wetenschappen leert ons daarentegen door de ervaring dat de kennis van de wetten der Natuur ons het middel geeft om de Natuur dwars in den weg te treden, om ze zo te overwinnen met haar eigen wapenen. ${ }^{36}$
}

In 1900 had Mac Leod zich daarenboven ook al van de deterministische interpretatie van de natuurlijke selectie gedistantieerd. Op een lezing voor het Vlaams Natuur- en Geneeskundig Congres sprak hij toen als volgt:

essai sur les origines de l'humanité', Bulletin de la Société belge de géologie, de paléontologie et d'bydrologie [BSB], XXII (1908) 151-169; Idem, 'Sur l'authenticité du squelette féminin non-néanderthaloïde rencontré par Em. Rivière dans l'abri de Bourges', BSB, XXIV (1910) 375-377; Idem, 'Les origines de l'humanité', $B A R$, reeks 5, XII (1926) 989.

34 Idem, Les grandes mutations intellectuelles de l'bumanité, I, D' Où venons-nous? Que sommes nous? (Brussel, 1919) 154-155.

35 J. Dallemagne, Anarchie et responsabilité (Brussel, 1895) 7.

$36 \mathrm{~J}$. Mac Leod, Inleiding tot de natuurkunde der maatschappijen, 4. 
De leer die de vervolmaking der levende wezens zoekt in den strijd voor het bestaan en in de uitroeiing van den zwakke, kent geen ander middel tot vervolmaking van de menschelijke maatschappijen dan de dood, die de rijen komt dunnen om de harmonie te herstellen. Troostvol komt de studie van de levensvoorwaarden ons verkondigen, dat de Natuur ook middelen kent om de zwakke sterk te maken en voor den dood te vrijwaren, om te veredelen zonder te verdelgen. ${ }^{37}$

Door actief te morrelen aan de 'levensvoorwaarden' (of met andere woorden aan het milieu) kon men volgens Mac Leod de inhumane natuurlijke selectie zonder meer omzeilen.

Mac Leods denkbeelden zijn te kaderen binnen die van een veel grotere groep voluntaristen die vanaf de jaren 1880 de evolutieleer voor haar eigen doeleinden zou aanwenden. Ze beriepen zich daarbij ten dele op dezelfde biologische axioma's als de deterministen. Ook de 'evolutionair voluntaristen' geloofden met andere woorden in de fundamentele ongelijkheid tussen mensen - al verkozen ze vaak de term 'ongelijksoortigheid'. ${ }^{38}$ Daarenboven waren ze, meer nog dan hun deterministische collega's, geneigd om de nadruk te leggen op het belang van de verdeling van de arbeid. Dit is bijvoorbeeld erg duidelijk in het werk van de Brusselse socioloog en socialist Guillaume de Greef. In verschillende sociologische traktaten zou deze immers benadrukken dat maatschappelijke evolutie eigenlijk als groeiende arbeidsverdeling kon worden geïnterpreteerd. Evolutie leidde volgens hem tot een toenemende heterogeniteit in de samenleving (of een differentiatie van de delen), wat op zijn beurt gepaard ging met een toenemende centralisatie (of coördinatie van de delen). Dit alles vereiste tegelijkertijd een steeds groeiende solidariteit. ${ }^{39}$

Een dergelijk proces van toenemend 'solidarisme' werd in de visie van De Greef niet automatisch door natuurwetten gegenereerd, maar kwam voort uit een actief streven naar een ideaal. Indien er politiek verstandige keuzes werden gemaakt, dan kon de progressieve evolutie van het verleden zich oneindig voortzetten in de toekomst, aldus De Greef. Via een doordacht 'wetenschappelijk socialisme' kon men volgens hem langzaam een mondiale staat creëren waarin de afhankelijkheid van de delen totaal was. De sociale tegenstellingen zouden daarom - in tegenstelling tot wat Marx had beweerd - niet op de spits worden gedreven, maar integendeel gradueel vervagen. Als resultaat hiervan zou de hele wereld volgens De Greef worden samengebracht in één harmonisch en solidair lichaam. ${ }^{40}$

Degeneratie behoorde in het wereldbeeld van de 'evolutionair voluntaristen' weliswaar tot de mogelijkheden, maar het fenomeen maakte voor hen geen noodzakelijk onderdeel uit van de vooruitgang. Dit impliceerde dat men niet moest afwachten tot 'minderwaardige elementen' werden geëlimineerd door de natuurlijke selectie, maar dat men actief hun 'genezing' of (in minder geneeskundige termen) hun verheffing kon nastreven. Niet het fatalistische 'laissez faire', maar wel een

37 Idem, 'De invloed der levensvoorwaarden en de sociale verantwoordelijkheid', Handelingen van het Vierde Vlaamsch Natuur-en Geneeskundig Congres (Brussel, 1900) 151.

38 Zie bijvoorbeeld: Idem, Inleiding tot de natuurkunde, 6.

39 G. de Greef, Introduction à la sociologie, I, Eléments (Brussel-Parijs, 1886) 47-48, 116-131 en 151-152; Idem, Les lois sociologiques (Parijs, 1893) 169; Idem, Le transformisme social. Essai sur le progrès et le régrès des sociétés (Parijs, 19012) xxvi en 307-310.

40 Idem, La structure générale des sociétés, III, Théorie des frontières et des classes (Brussel-Parijs, 1908) 339-401. 
voluntaristisch 'arbeid en vertrouwen' gold daarbij als politieke leuze. ${ }^{41}$ Deze arbeid kon zowel slaan op moralisering en opvoeding van de lagere sociale klassen als op hygiënistische maatregelen tegen tbc, venerische ziekten of alcoholisme. De impact van het (sociaal én fysisch) milieu gold daarbij steeds als cruciaal. Met een boutade stelde De Greef in 1907: 'Voor een kippenei kan zowel de omelet als de kip een vorm van aanpassing zijn, al naargelang het milieu waarin het wordt geplaatst. ${ }^{42}$

Het geschetste voluntaristisch wereldbeeld ging gepaard met een heel eigen visie op erfelijkheid en op het evolutionair proces. Zo fundeerde Mac Leod zijn denkbeelden over de maakbaarheid van de mens met erfelijkheidsopvattingen die hij ontleende aan de Nederlandse botanicus Hugo De Vries - weliswaar uit de periode vóór dat die laatste zijn mutatietheorie had ontwikkeld. ${ }^{43}$ Centraal in Mac Leods erfelijkheidsleer stonden 'verborgen kiemen', die slechts in daadwerkelijke kenmerken resulteerden als ze geactiveerd werden door de omgeving. Omdat elke mens op een haast eindeloos aantal voorouders terugging, geloofde Mac Leod dat ook het aantal verborgen kiemen per individu erg groot was. Dit impliceerde dat, mits een 'beredeneerde regeling van de voorwaarden waaronder de mensch opgroeit en in volwassen toestand leeft', men gunstige kiemen kon laten ontluiken en het individu in belangrijke mate kon 'kneden'. ${ }^{44}$

Mac Leods eigenzinnige erfelijkheidsleer kende echter relatief weinig navolging. Meer succes was er weggelegd voor een ander mechanisme dat een belangrijke evolutionaire rol liet toekomen aan de rechtstreekse invloed van het milieu, namelijk de lamarckistische overerving van verworven eigenschappen. De Greef was er een verdediger van, net als de invloedrijke pedagoog Jean Demoor en de toonaangevende crimineel-antropoloog Louis Vervaeck. ${ }^{45}$ Deze auteurs gebruikten het lamarckisme in de eerste plaats als verklaring van degeneratieve verschijnselen. Dergelijke fenomenen waren volgens hen enkel te verklaren doordat een pathologische omgeving pathologische organismen voortbracht en niet (zoals in een neo-darwinistische logica) gezonde overlevers. ${ }^{46}$ Hun lamarckisme leidde daarbij tot optimisme. Het wegnemen van de problematische omgeving zorgde immers niet alleen voor een tijdelijke oplossing. De gunstige effecten lieten ook hun sporen in de erfelijkheid na.

Wanneer het lamarckisme omstreeks 1900 in sommige milieus onder vuur kwam, lieten enkele 'evolutionair voluntaristen' het varen. Tegelijkertijd bleven ze echter

41 Idem, Le transformisme social, i.

42 Idem, La structure générale des sociétés, I, La loi de limitation (Brussel-Parijs, 1907) 234.

43 Het gaat over De Vries' erfelijkheidstheorieën uit de jaren 1890. Zie hierover: I.H. Stamhuis, O.G. Meijer, E.J.A. Zevenhuizen, 'Hugo de Vries on heredity 1889-1903. Statistics, mendelian laws, pangenes, mutations', Isis: An International Review devoted to the History of Science an its Cultural Influences, XC (1990) 243-246.

44 J. Mac Leod, Erfelijkheid (s.l., 1896) 278-342.

45 De Greef meende in de lijn van de Engelse socioloog en psycholoog Herbert Spencer dat natuurlijke selectie vooral een rol speelde bij planten en lagere diersoorten. In de evolutie van hogere diersoorten speelde volgens hem vooral de lamarckistische overerving. De Greef, Le transformisme social, 422. Voor de lamarckistische ideeën bij Demoor en Vervaeck, zie onder meer: J. Demoor, Die abnormalen Kinder und ihre erziehlighe Behandlung in Haus uns Schule (Altenburg, 1901) 10-13; L. Vervaeck, 'L'importance dans l'évolution des phénomènes de mutation', $B S A B$, XXXI (1912) cxvii-cxiv en cxxiv-cxxvii.

46 R.A. Nye, 'The bio-medical origins of urban sociology', Journal of Contemporary History, XX (1985) 663. 
vasthouden aan een 'metaforisch lamarckisme'. Een goed voorbeeld biedt hier de socioloog en latere socialistische voorman Emile Vandervelde. In een werk dat hij in 1897 (samen met Demoor en de neo-darwinistische botanicus Jean Massart) publiceerde, werd benadrukt dat individuele morfologische aanpassingen niet werden overgeërfd. Op het niveau van de sociologie kon men volgens Vandervelde echter vaststellen dat maatschappelijke aanpassingen wél de overstap maakten naar een volgende generatie. Niet zozeer erfelijkheid als wel imitatief gedrag gold hier als de verklarende factor. ${ }^{47}$ Ondanks het feit dat het letterlijk lamarckisme hier dus werd losgelaten, bood het 'metaforisch lamarckisme' Vandervelde een argument voor de maakbaarheid van de samenleving.

Het voluntaristische aspect in de angehaalde denkbeelden school erin dat niet enkel het individu zich kon aanpassen aan het milieu, maar dat ook omgekeerd het milieu kon worden aangepast aan het individu. Dit is bijvoorbeeld erg duidelijk in de crimineel-antropologische projecten van Vervaeck. Omdat de meerderheid van de criminelen in zijn ogen gedegenereerd was, drong zich volgens hem een gedifferentieerd systeem van 'heraanpassing' op. Hij pleitte daarom voor gevangenissanatoria voor tuberculosepatiënten, penitentiaire hospitalen voor invaliden, grijsaards en sociaal gevaarlijke zieken, psychiatrische kolonies voor epileptici en hysterici, landbouwkolonies voor 'mentale debielen', penitentiaire kolonies voor drinkers en toxicomanen, instellingen voor psychiatrische criminelen en aparte secties voor morele gekken en seksuele maniakken. ${ }^{48}$

Zeer gelijksoortige ontwikkelingen kunnen worden vastgesteld in de experimentele pedagogie, zoals die ontwikkeld werd door Demoor en de arts Ovide Decroly. Hier heette het dat men het kind in belangrijke mate kon boetseren als men het op het juiste moment met het juiste milieu in aanraking bracht. In die context vergeleek Decroly de taak van de 'evolutionistische pedagoog' met die van de veeteler. Op basis van het experiment moest deze uitzoeken welke milieufactoren hij wilde uitschakelen en welke hij wilde doseren om het organisme de gewenste kenmerken te geven. ${ }^{49}$ In dezelfde lijn liggen tenslotte ook de denkbeelden die Decroly's vriend, de ingenieur en socioloog Emile Waxweiler, ontwikkelde over de Belgische kolonisatie van Congo. Tegen de traditionele concepties in, meende Waxweiler dat in eerste instantie de functies van de Congolese maatschappij moesten worden ontrafeld om vervolgens de Congolezen te verheffen via een 'wetenschappelijke' aanpassing van hun milieu. ${ }^{50}$ Hiermee week hij uiteraard af van een deterministisch geloof in de erfelijke inferioriteit van niet-Europese rassen.

47 J. Demoor, J. Massart, E. Vandervelde, L’Evolution régressive en biologie et en sociologie (Parijs, 1897) 244-247. Voor een hedendaagse variant van deze redenering zie: S.J. Gould, 'More things in heaven and earth', in: Rose, Rose, ed., Alas, poor Darwin, 98.

48 L. Vervaeck, 'Syllabus du cours d'anthropologie criminelle donné par le Dr. Vervaeck', BSAB, XL (1925) 339-342. Zie uitgebreider over Vervaeck: R. De Bont, 'Meten en verzoenen. Louis Vervaeck en de criminele antropologie, 1900-1940', in: J. Tollebeek, G. Vanpaemel, K. Wils, ed., Degeneratie in België, 1860-1940. Een geschiedenis van ideeën en praktijken (Leuven, 2003) 185-225.

49 O. Decroly, 'La pédagogie évolutionniste', L’Enseignement Pratique. Revue Bi-Mensuelle de Pédagogie et d'Education Lä̈que, XVII (1909) 4.

50 F. v.[an] L.[angenhove], 'Groupe d'études coloniales et groupe d'études sociologiques - Réunion du 27 avril', Archives sociologiques, III (1912) 1537-1541. 
Het voluntarisme vond zelfs zijn weg naar de doelstellingen van de jonge laatnegentiende-eeuwse wetenschappen. Zo was de sociologie van De Greef expliciet opgevat als een discipline die de socialistische streefdoelen van een wetenschappelijke basis moest voorzien. En ook de experimentele pedagogie van Demoor had maar zin in een voluntaristische context. In 1929 vroeg die zich dan ook openlijk af: 'Waarom scholen openen en er kinderen ontvangen met het idee wezens, hersens en harten te vormen als het waar is dat een fatale erfelijkheid alle energie die daarvoor nodig is, verstikt? ${ }^{51}$ Het belang van erfelijkheid werd door wetenschappers als Demoor niet ontkend - hij was er immers van overtuigd dat die in de opvoeding expliciet in rekening moest worden gebracht - maar ze kon wél in belangrijke mate worden overstegen.

Hoewel het evolutionair voluntarisme vaak samenging met een bepaald gelijkheidsideaal, leidde het allerminst tot een ontkenning van het belang van de elite. In een brief aan de Brusselse bioloog Léo Errera stelde Waxweiler het als volgt:

\footnotetext{
Er is niets nuttiger in de sociologie dan zich bezig te houden met de activiteit, het lot en de noden van de massa's. Maar we mogen echter niet uit het oog verliezen wat de bewaring en de versterking van de elite in de hand kan werken, want het is uiteindelijk zij die de rol van motor vervult in de sociale vooruitgang. ${ }^{52}$
}

Bij Mac Leod kregen dezelfde ideeën een Vlaamsgezinde bijklank. Hij benadrukte dat het de taak van 'de hoogst ontwikkelde elementen van ieder volk' was om de belangrijkste verworvenheden uit andere culturen voor de massa toegankelijk te maken. Dit was volgens Mac Leod noodzakelijk omdat de volksmassa's uit zichzelf geneigd waren tot 'onvruchtbare nabootsing van uiterlijke vormen' - een fenomeen dat duidelijk verwees naar de verfransing van de Brusselse volkslagen en dat hij vergeleek met 'het ontstaan van bastaarden bij dieren en planten. ${ }^{, 53}$

Dat de elite van 'voorlopers' een plicht had ten opzichte van de 'achterblijvers' werd door de evolutionair voluntaristen vrij algemeen aangenomen. De pedagogen Demoor als Decroly verdedigden hun bekommernis voor het abnormale kind zelfs volledig vanuit die redenering. De degeneratie van abnormale kinderen was slechts een nevenproduct van de progressieve evolutie, zo heette het bij hen. Het was dan ook de verantwoordelijkheid van de elite die van de evolutionaire vooruitgang profiteerde om de achtergeblevenen te ondersteunen en te verheffen. ${ }^{54}$

\section{De gewrongen positie van de Belgische engenetica}

De voluntaristische en de deterministische interpretatie van het evolutionair proces sloten elkaar nooit helemaal uit. Dit blijkt waarschijnlijk het duidelijkst uit de geschiedenis van de Belgische eugenetische beweging, die steeds de twee elementen

51 J. Demoor, T. Jonckheere, La science de l'éducation (Brussel-Parijs, 1925) 49.

52 Dit maakte zelfs dat Waxweiler niet geheel afkerig stond van (proto-)eugenetische maatregelen. Waxweiler aan Errera, ongedateerd [1905], Archives de l'Université de Bruxelles, Fonds L. Errera, 20PP.

53 Mac Leod, Inleiding tot de natuurkunde der maatschappijen, 14.

54 J. Demoor, T. Jonckheere, La science de l'éducation (Brussel-Parijs, 1925³) 68-69; O. Decroly, 'Le traitement et l'éducation des enfants irréguliers', Association des pédiatres de langue française.Troisième congrès, Bruxelles (Brussel, 1924) 138-139. 
heeft verenigd. Enerzijds werd in de Sociéte belge d'eugénique regelmatig verwezen naar (Anglo-Amerikaanse) beginselverklaringen waarin erfelijkheidsdeterminisme en het belang van de selectie van 'erflijnen' centraal stonden. ${ }^{55}$ Anderzijds bleef de sociëteit steeds in belangrijke mate verbonden met een Belgische traditie van hygiënisme en preventieve geneeskunde - die zich eerder in de verheffing dan in de selectie van individu's had gespecialiseerd. ${ }^{56}$ Precies omwille van de kracht van deze traditie was de term 'eugenetica' lange tijd problematisch. In 1913 nog verzette Max Boulenger, de latere voorzitter van de Société, zich tegen het gebruik van de term omdat die te 'hereditaristisch' klonk. Zelf benadrukte hij dat er veel te bereiken was door 'de invloed van het milieu op de mens en de schepping van het milieu door de mens'. Zolang die middelen niet uitgeput waren vond hij het niet nodig om reeds aan de artificiële selectie van erfelijk materiaal te denken. ${ }^{57}$

Precies dat laatste programma werd na de Eerste Wereldoorlog wél verdedigd door enkele eugenetici die onder de indruk waren geraakt van de mendeliaanse genetica zoals Albert Govaerts, Norbert Ensch of Eugène Willems. Dergelijke artsen droomden er hardop van om via artificiële selectie de voortplanting van een 'natuurlijke elite' te bevorderen en die van gedegenereerden tegen te werken.

Tegelijkertijd gaven ze meteen aan dat dit einddoel nog veraf was. Ze stelden immers vast dat selectieve maatregelen (zoals de sterilisatie van zogenaamde minderwaardigen) slecht lagen bij de publieke opinie. Daarenboven moesten ze ook vaststellen dat hun kennis over de erfelijkheid nog niet gevorderd genoeg was om een dergelijk project ten uitvoer te brengen. ${ }^{58}$ Voorlopig, zo meenden ze, moest de preventieve geneeskunde dan maar een uitweg bieden.

Doordat zowel de logica van de voluntaristische preventieve geneeskunde als die van een erfelijkheidsdeterministische genetica werd gevolgd, bleef de Société belge d'eugénique een enigszins gespleten onderneming. Die gespletenheid blijkt nog het duidelijkst in de teksten van haar voorzitter, Boulenger. In het openingsnummer van de Belgische Revue d'engénique in 1921 stelde deze dat 'de menselijke geest schippert tussen de vernietiging van de gebrekkige en zijn behoud, ondanks alles.' Boulenger durfde er wel eens van dromen dat eugenetische ingrepen zouden zorgen voor een overwicht van fysiek krachtige intellectuelen (naar het voorbeeld van de Griekse god Apollo), maar intussen vond hij dat men zich vooral moest concentreren op hygiënistische ingrepen. 'Welk doel schuilt erin', zo vroeg hij zich af, 'om sterke,

55 Ondanks dergelijke beginselverklaringen waren in de Anglo-Amerikaanse wereld overigens óók duidelijk tendensen aanwezig die in de eerste plaats de nadruk legden op het belang van het milieu. Zie onder meer: M. Freeden, 'Eugenics and progressive thought: A study in ideological affinity', History Journal, XXII (1979) 645-672.

56 Die dubbelzinnigheid blijkt duidelijk in: M. Boulenger, 'La question eugénique', Revne d'Eugénique. Organe de la Société belge d'Eugénique, I (1921) 2-8. Over de Belgische hygiënistische traditie: L. Nys, 'Nationale plagen. Hygiënisten over het maatschappelijk lichaam', in: L. Nys, H. Desmaele, J. Tollebeek, K. Wils, ed., De zieke natie. Over de medicalisering van de samenleving, 1860-1914 (Groningen, 2002) 220-241.

57 M. Boulenger, 'Influence du milieu sur l'homme et création du milieu par l'homme', BSAB, XXXII (1913) ccxlv-cclxv.

58 N. Ensch, 'Y-a-t-il un mouvement eugénique en Belgique?', E. Willems, 'La politique eugénique' en A. Govaerts, 'L'eugénique', opgenomen in: C. Gini, ed., Le problème engénique en Belgique (Rome, s.a.) respectievelijk 13-20, 157-179 en 292-312. 
gezonde en intelligente wezens te selecteren als ze hun kinderen moeten opvoeden in krotten, in woningen van één kamer, in industrieën die ze doden, in een samenleving die de moed niet heeft om het alcoholisme te bestrijden? ${ }^{59}$

De tweevoudige inspiratie van de Belgische eugenetische beweging ging samen met een enigszins dubbelzinnige houding ten aanzien van het erfelijkheidsmechanisme. Enerzijds beleden verschillende Belgische eugenetici hun geloof in de 'harde' erfelijkheidsopvattingen van de Duitse bioloog August Weismann, die had gesteld dat de kiemcel geen enkele invloed van het milieu onderging. ${ }^{60}$ Anderzijds bleven ze grotendeels trouw aan oude degeneratietheorieën, waarin een lamarckiaanse 'zachte' erfelijkheid werd verondersteld. In een eigenzinnige combinatie van de twee opvattingen meenden onder meer Govaerts en Ensch dat het milieu nooit voor verbetering van het erfelijk materiaal kon zorgen, maar dat het dit wél kon 'verstoren'. Het milieu was dus enkel een bron van degeneratie, nooit van raciale verbetering. In die redenering kon de preventieve geneeskunde enkele problemen vermijden, maar kon het nooit een cruciale vooruitgang van het ras forceren. Daarvoor bleven Govaerts en de zijnen hun hoop vestigen op een actieve eugenetische tussenkomst in de menselijke voortplanting. ${ }^{61}$

Voor eugenetische deterministen was het verheffen van het individu een onmogelijke taak. Via artificiële selectie kon men echter wél de mensheid als geheel naar een betere toekomst voeren. De enkeling mocht dan al niet maakbaar zijn, het ras was dat in hun ogen wel degelijk. De actieve tussenkomst die ze bepleitten, kwam er echter niet. 'De religie van het krachtige en pure ras' van de Belgische eugenetici leidde nooit tot de radicale maatregelen die wel in Duitsland, Scandinavië en de Verenigde Staten werden genomen. ${ }^{62}$ Dit lijkt althans gedeeltelijk te verklaren door het belang van de voluntaristische stroming binnen de Société belge d'eugénique. Decroly en Vervaeck toonden er zich vrij actieve leden, net als een hele reeks andere vooraanstaande figuren uit de hygiënistische beweging. In de ledenlijst treffen we boegbeelden van antialcoholische liga's, hygiënische diensten van de overheid en reformpedagogische instellingen. ${ }^{63}$ Deze groep temperde ongetwijfeld de ambities van de erfelijkheidsdeterministen. Die slaagden er weliswaar gedeeltelijk in om hun retoriek ingang te doen vinden, maar hun dromen over een artificiële selectie van menselijk materiaal bleven onvoltooid.

59 Boulenger, 'La question eugénique', 3, 5 en 7.

60 Over Weismann's opvattingen: F.B. Churchill, 'August Weismann. A developmental evolutionist', in: A. Weismann, Ausgewäblte Briefe und Dokumente (Freiburg, 1999) 749-798.

61 N. Ensch, 'La médecine préventive et la sélection naturelle (thèses anti-hygiéniques)', La vie intellectuelle, III (1909) 208-221; Govaerts, 'L’eugénique', 294-295.

62 Het citaat komt uit: Boulenger, 'La question eugénique', 3; Over de aangehaalde buitenlandse ontwikkelingen zie onder meer: D. Kevles, In the name of engenics: genetics and the uses of buman beredity (New York, 1985); N. Roll-Hansen, 'Geneticists and the eugenics movement in Scandinavia', British Journal for the History of Science, XXII (1989) 335-346; P. Weindling, Health, race and German politics between national unification and nazism, 1870-1945 (Cambridge, 1991); P. Crook, 'American eugenics and the Nazis. Recent historiography', European Legacy, VII (2002) 363-381.

63 Zo was Boulenger zelf directeur van de Ferme Ecole de Waterloo en secretaris van het Office antialcoolique. 


\section{Gedepolitiseerde politiek}

De eugenetische casus toont aan dat het evolutionair determinisme en voluntarisme niet als gescheiden werelden moeten worden gezien. De propagandisten van beide strekkingen deelden een gelijkaardige sociale achtergrond en ze vonden elkaar in dezelfde wetenschappelijke sociëteiten en instituten. Bovendien deelden ze ook een (grotendeels) gemeenschappelijk biologisch referentiekader. Het was dan ook niet uitzonderlijk dat evolutionair deterministen in voluntaristische zin evolueerden of omgekeerd. ${ }^{64}$ Over de maakbaarheid van de mens bestond weliswaar een heftige discussie, maar scherp afgelijnde clans bestonden er in dat debat nooit.

De focus van de geschetste discussies betrof uiteraard de kracht van het menselijk handelen. Evolutionair voluntaristen geloofden dat men de evolutie kon sturen door het individu te verheffen. Ze meenden immers dat de mens via zijn milieu ook zichzelf kon veranderen. Voor de deterministen lag de zaak enigszins anders. Sommigen onder hen geloofden in een onverbiddelijke natuurwet, die eender welke interventie in het evolutionaire proces onmogelijk maakte. In hun hoek werd dan ook erg schamper gesproken over 'de kinderlijke ambitie om zelf de wetten van het leven te dicteren, de evolutie te beteugelen en het te begeleiden als was het een gedresseerd paard. ${ }^{, 65}$ Anderen combineerden hun erfelijkheidsdeterministisch standpunt met een eugenetisch project waarin de mens zijn eigen evolutie alsnog in handen zou nemen. Het was niet door de verheffing van het individu, maar ten koste van het individu dat deze deterministische eugenetici de evolutionaire toekomst van het ras wilden veiligstellen. Hun radicale project verleidde in België echter maar een minderheid.

De kern van het meningsverschil tussen evolutionair deterministen en voluntaristen ging over politiek handelen. Niettemin deelden beide groepen dezelfde grondopvatting waar het de politiek betrof. Ze vonden elkaar immers in de idee dat politiek, om goede politiek te zijn, zich moest baseren op de 'objectieve kennis' van de evolutionaire wetenschap. Dit impliceerde dat politici zich niet mochten richten op partijpolitieke belangen (die de samenleving verdeelden), maar dat ze steeds het 'objectieve' belang van het sociaal organisme als geheel moest nastreven. In dat opzicht pleitten zowel deterministen als voluntaristen voor een gedepolitiseerde politiek. Het was de afstandelijke wetenschapper en niet de partijman die de menselijke evolutie op het juiste spoor kon houden. Het was ook dat wat Julius Mac Leod bedoelde, toen hij in 1900 aan zijn vriend August Vermeylen schreef: 'In de loop van de eeuw waarvan de dageraad aanbreekt, zullen genie en talent de wetenschap gebruiken om de maatschappij te veredelen; De politiek heeft hare taak niet kunnen volbrengen; het woord is aan de wetenschap. ${ }^{, 66}$

Raf de Bont (1977) is als postdoctoraal onderzoeker (FWO-Vlaanderen) verbonden aan de onderzoekseenheid Cultuurgeschiedenis vanaf 1750 aan de KULeuven.

64 Houzé is een goed voorbeeld van de eerste evolutie. Aan het begin van de twintigste eeuw zou deze (onder meer onder invloed van Waxweiler) zijn determinisme temperen en steeds meer ruimte laten voor de maakbaarheid van de mens.

65 Van Drunen, 'Socialisme scientifique', 347.

66 Julius Mac Leod aan August Vermeylen, 31 dec. 1900, Archief en Museum voor het Vlaamse Cultuurleven, M1505/B1. 
Summary

Raf de Bont, To elevate or to exterminate? Evolution theory and 'Man's ability to be transformed'.

Around 1900, Belgian scientists from different disciplines were tempted to use the theory of evolution as a tool to make pronouncements about 'Man's ability to be transformed'. Although some biologists did examine this issue, it was primarily sociologists, anthropologists, educationalists, criminologists and eugenicists who used biological language to tackle the question. In this article $I$ argue that these commentators can be divided into two groups: the determinists and the voluntarists. The first tended to believe in an evolution that was determined by an insurmountable struggle for life. A larger group of voluntarists, however, believed human evolution could be adjusted by changing the milieu in which people lived. In spite of this difference, the two groups also had a lot in common. Both used biological terminology to argue for a new type of government which was completely 'objective' and 'scientific'. In this way, both became defenders of what can be described as a 'depoliticization' of politics. 


\title{
'Mensen ... worden niet geboren maar gevormd': Erasmus en het principe van de opvoeding
}

\author{
JAN VAN HERWAARDEN
}

Waarom is de schoolmeester geschapen? Niet om zo maar wat rond te dartelen, maar om met de vrije wetenschappen zijn geest te vormen. ${ }^{1}$

\section{Enkele treffende witgangspunten}

Het citaat 'mensen ... worden niet geboren maar gevormd' verwoordt de kern van Erasmus' opvattingen. ${ }^{2}$ Het staat in De pueris statim ac liberaliter instituendis, wat zo veel wil zeggen als 'Over de verplichting kinderen terstond en ruimdenkend op te voeden', de bekendste verhandeling die Erasmus over opvoeden en onderwijs heeft geschreven. ${ }^{3}$ Even verderop staat daarin te lezen: 'De rede maakt de mens', wat zo kort als het is Erasmus' overtuiging feilloos weergeeft. ${ }^{4}$ De natuur, waarin Gods voorzienigheid zich manifesteert, bepaalt dat de mens zich door de rede van het dier onderscheidt. ${ }^{5}$ Dat onderscheid verplicht de mens tot ontwikkeling. Een kind moet worden opgevoed en onderwezen, want'tot wat voor een wild en nutteloos schepsel zal een mens uitgroeien, tenzij hij van jongsaf een grondige vorming krijgt?' In dat 'nutteloos', inutilis,

1 J. Chomarat, ed., Ecclesiastes (Libri I-II), ASD, V.4 (Amsterdam, 1991) 390, 11. 583-584.

2 Desiderius Erasmus, De opvoeding van kinderen, in: Verzameld Werk, III, Opvoeding, vertaald door Jeanine de Landtsheer en Bé Breij (Amsterdam, 2006) 63-65: inleidende brief; 66-132: tekst; 76; J.-C. Margolin, ed., De pueris statim ac liberaliter instituendis, ASD, I.2 (Amsterdam, 1971) 3-19: inleiding; 21-22: inleidende brief; 23-78: tekst; 31, 1. 21; zie ook: Érasme, Declamatio de pueris statim ac liberaliter instituendis, J.-C. Margolin, ed., (Genève, 1966) 389 en noot 134, p. 494; B. C. Verstraete, ed., A declamation on the subject of early liberal education for children (Toronto-Buffalo-Londen, 1985) 292-346 (inleiding en tekst); 567-580 (noten); 304.

3 Deze verhandeling diende ook als bron voor de beknopte beschouwing die Jan Noordman aan Erasmus wijdde in: N. Bakker, J. Noordman, M. Rietveld-van Wingerden, Vijf eeunven opvoeden in Nederland. Idee en praktijk, 1500-2000 (Assen, 2006) 9-13: 'Erasmus'; vergelijk de opmerkingen van Marjoke Rietveld-van Wingerden over de kritiek van de humanisten op het destijds bestaande onderwijssysteem, 'Onderwijs in de republiek', Vijf eeunven opvoeden in Nederland, 417-453; 423-425.

4 Opvoeding, 76; De pueris, ASD, I.2, 31, 1. 23; vergelijk Declamatio, 389 en noot 136, p. 494.

5 Opvoeding, 87: Wat is nu het meest kenmerkend voor de mens? Leven volgens zijn rede toch, want daarom wordt hij een redelijk wezen genoemd en onderscheiden van de dieren; De pueris, ASD, I.2, 40, 11. 21-22; Erasmus heeft het verderop over de naturae providentia, De pueris, ASD, I.2, 46, 1. 24, vergelijk Opvoeding, 94; het plan van de natuur en de goddelijke voorzienigheid zijn niet met elkaar in strijd, want de natuur is door God geschapen, aldus Margolin in: Declamatio, 413 en noot 411, p. 529.

6 Opvoeding, 72; De pueris, ASD, I.2, 29, 11. 8-9; vergelijk Declamatio, 385 en noot 93, p. 487; zie ook Noordman, 'Erasmus', in: Bakker,e.a., Vijf eeuwen opvoeden in Nederland, 12: 'een mens die niet 'doordrenkt is met de beste kennis' is tomeloos en gevaarlijker dan welk dier dan ook.' 